\title{
Helsepersonell må bry seg mer om barnas foreldre
}

Godt samarbeid mellom helsepersonell og foreldre til barn på sykehus, kan gi barnet og familien et bedre helsetilbud. Det krever at helsepersonalet har høy kommunikasjons- og relasjonskompetanse.

\section{Forfatter}

\section{Antje Aarthun}

Fysioterapeut

Det helsevitenskaplige fakultet, Universitetet i Stavanger

\section{Nøkkelord}

\section{Barn Brukermedvirkning Pårørende Sykehus}

Sykepleien 2018 106(72752)(e-72752)

DOI: https://doi.org/10.4220/Sykepleiens.2018.72752

\section{HOVEDBUDSKAP}

Helsepersonell har en viktig rolle ved involvering av foreldre i beslutningene om barns helsetilbud. Ny forskning rapporterer at foreldrene var opptatt av sitt barns helsetilbud, samtidig som de var i en krevende og sårbar situasjon under beslutningene om helsetilbudet. Måten helsepersonellet involverte foreldrene i beslutningene om unders $ø$ kelser og behandling som barnet skulle igjennom, påvirket foreldrenes medvirkning, mestring av foreldrerollen og kvaliteten på helsetilbudet. 
Aarthun, Akerjordet og Øymars forskning $(1,2)$ viser at foreldrene var i en krevende og sårbar situasjon da barnet deres fikk helsehjelp på sykehuset. I tillegg varierte det i hvor stor grad helsepersonellet tilrettela for foreldrenes medvirkning i beslutningene om utformingen av barnas helsetilbud. Beslutningene gjaldt individuelle tilpasninger av undersøkelser og behandling til barna, inkludert hvordan foreldrene skulle bistå.

Offentlige dokumenter har i flere år gitt føringer om at helsepersonell må bedre pasientenes brukermedvirkning og gi et pasientsentrert helsetilbud $(3,4)$. Dette gjelder også for barn som pasienter, og foreldre som brukerrepresentanter for sitt barn (5). Hvilke erfaringer har foreldre om brukermedvirkning fra opphold på barneavdelinger?

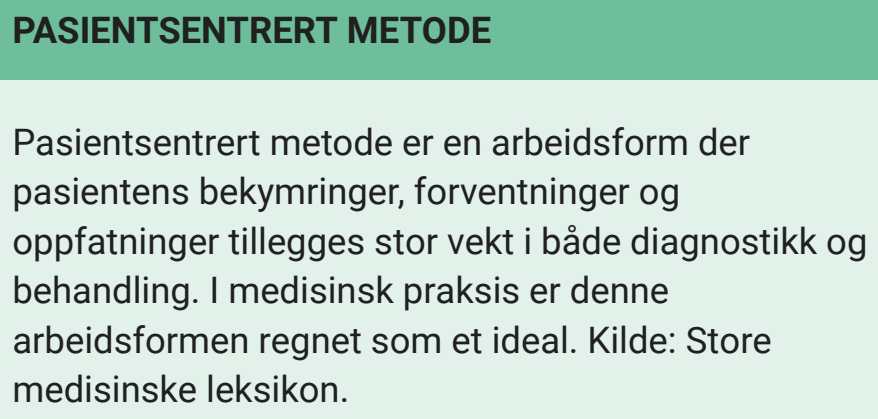

\section{Krevende for foresatte}

Foreldre til barn på sykehus har en viktig og omfattende rolle. De gir omsorg til sitt barn, gir informasjon til helsepersonell om barnets helsetilstand og bistår ofte under undersøkelser og behandling. I tillegg skal foreldrene ivareta barnets behov og interesser gjennom retten til å gi samtykke til helsehjelp, og medvirke i beslutningene om utformingen av barnets helsetilbud (5).

Aarthun, Akerjordet og Øymar $(1,2)$ undersøkte foreldres erfaringer og oppfatninger om deres medvirkning i utformingen av barnets helsetilbud på sykehus og helsepersonells tilrettelegging for dette. 
De to kvalitative studiene viste at det varierte i hvor stor grad foreldrene fikk mulighet til å medvirke.

Videre var det ulikt hvor mye kunnskap foreldrene hadde om barnets helsetilstand og det foreslåtte helsetilbudet. Foreldrene syntes det var vanskelig å ta stilling til hvilke undersøkelser og behandlinger som var best for barnet, fordi de hadde for liten medisinsk og helsefaglig kunnskap. De hadde imidlertid stor tillit til helsepersonellets kompetanse.

\section{三 «Foreldrene syntes det var vanskelig å ta stilling til hvilke undersøkelser og behandlinger som var best for barnet.»}

Foreldre med mye erfaring i oppfølging av barn på sykehus, hadde mer kunnskap om sine barns helsetilstand, behov og helsetilbud og medvirket $\mathrm{i}$ større grad i beslutningene om utformingen av helsetilbudet (1). Andre fikk mangelfull informasjon og var svært usikre og utrygge i situasjonen. Det førte til at det var krevende for dem å medvirke i utformingen av helsetilbudet og bistå i behandlingen av barnet, spesielt hvis helsepersonellet var lite samkjørte i informasjonen og helsetjenesten barnet kunne få.

Andre foreldre var sterkt emosjonelt berørt over sitt barns helsetilstand og mestret i mindre grad å medvirke i utformingen av helsetilbudet. Foreldrene var derfor avhengig av at helsepersonell identifiserte barnets og deres eget behov, for at barnet skulle få et godt tilpasset helsetilbud. 
Foreldre som både var emosjonelt sterkt berørt og som hadde liten kunnskap om barnets helsetilstand og helsetilbud, var i en svært krevende og sårbar situasjon. Andre sårbare grupper var foreldre med en annen kultur, foreldre med utenlandsk opprinnelse og de som hadde språkproblemer. De opplevde å bli misforstått av helsepersonell, og det virket negativt på samarbeidet mellom foreldre og helsepersonell om barnets helsetilbud $(1,2)$.

\section{Ønsket samtaler}

Foreldrene som fulgte barnet på sykehuset, ønsket hyppige samtaler med helsepersonell om barnets helsetilstand, behov og helsetilbud. De ønsket samtaler preget av dialog, tillit og gjensidig respekt der foreldre og helsepersonell kunne utveksle informasjon og drøfte barnets behov og hvilken behandling barnet kunne få.

\section{三 «De fikk en bedre forståelse av barnets helsetilstand.»}

Foreldrene som fikk samtaler med helsepersonell rapporterte at dialogen bidro til at de i større grad fikk informasjon som var tilpasset deres behov. De fikk en bedre forståelse av barnets helsetilstand, barnets behov og den planlagte helsehjelpen. Foreldrene ble da bedre i stand til å vurdere foreslåtte undersøkelser og behandling og komme med relevant informasjon og motforestillinger.

Samtalene ga dem også en større trygghet i at deres barn fikk rett type helsehjelp og et forsvarlig helsetilbud. Gjentatte tillitsskapende samtaler fremmet et godt samarbeid der foreldrene i større grad meldte fra om sine behov og sa sin mening. De fikk da en mulighet til å ta opp bekymringer og diskutere behandlingen. Det bidro til at de ble tryggere i foreldrerollen og mer tilfreds med helsetilbudet $(1,2)$.

\section{Avhengig av helsepersonell}


Forskningen viste at foreldre var avhengig av

helsepersonells kompetanse, velvillighet og pådriv for å få et godt tilpasset helsetilbud til sine barn $(1,2)$.

Foreldrene var avhengig av om, når og hvordan helsepersonell tilrettela for foreldresamarbeidet og hvorvidt de ble involvert i utformingen av helsetilbudet.

Foreldres avhengighet av helsepersonell førte til at det kunne være vanskelig å opptre fritt og si sin mening. Det var derfor krevende å gi kritikk og si ifra ved uenighet. Dette var især utfordrende og ubehagelig for foreldre som hadde en meget dårlig relasjon til enkelte helsepersonell (2).

Funnene fra studiene viste at helsepersonellets kommunikasjons- og relasjonskompetanse hadde stor betydning for kvaliteten på involveringen av foreldrene i beslutningene om barnas helsetilbud $(1,2)$.

Helsepersonellets sensitivitet ovenfor foreldrenes kapasitet og behov var især viktig i tilretteleggingen for foreldres medvirkning (2). God tilrettelegging for foreldrenes medvirkning i beslutningene om barns helsetilbud forutsetter imidlertid at helsepersonell virkelig ønsker å fremme samarbeidet med foreldre og deres brukermedvirkning (6).

\section{Konklusjon}

Undersøkelsene $(1,2)$ tyder på at når helsepersonell tilrettelegger for et godt foreldresamarbeid og involverer foreldre i beslutningene om barns helsetilbud, fremmes foreldres aktive medvirkning og det gir foreldrene bedre mulighet til å gi informasjon om barnet og familien. Helsepersonell kan da i større grad utforme barns helsetilbud i overensstemmelse med barns og familiers reelle behov.

\section{¿Et godt tilpasset helsetilbud til barnet gir vanligvis også en bedre situasjon for foreldrene.»}


Et godt tilpasset helsetilbud til barnet gir vanligvis også en bedre situasjon for foreldrene. Det fremmer deres mestring i den krevende foreldrerollen og det øker kvaliteten på barns helsetilbud på sykehus. God involvering av foreldrene i beslutningene om helsetilbudet krever at helsepersonell har høy kommunikasjons- og relasjonskompetanse.

For å oppnå et godt tilpasset helsetilbud trenger personalet støtte, tilrettelegging og gode prioriteringer fra ledelsen på sykehusene, slik at det er nok personale på jobb og at helsepersonellet får mulighet til å øke sin kompetanse.

Det er nødvendig med mer forskning på hvordan helsepersonell tilrettelegger for foreldrenes medvirkning, hvordan foreldre og helsepersonell samarbeider og om foreldres medbestemmelse bedres.

I tillegg er det behov for å få mer kunnskap om involvering av barn og ungdom i beslutningene om deres helsetilbud.

\section{Referanser}

1. Aarthun A, Øymar K, Akerjordet K. How health professionals facilitate parents' involvement in decision-making at the hospital: A parental perspective. J Child Health Care. 2018;22(1):108-21.

2. Aarthun A, Øymar K, Akerjordet K. Parental involvement in decision-making about their child's healthcare at the hospital. Nursing Open. 2018 Juni;19.

3. Meld. St. nr. 26 (1999-2000). Om verdier for den norske helsetjenesten. Oslo: Helse- og omsorgsdepartementet; 1999. Tilgjengelig fra: https:// www.regjeringen.no/no/dokumenter/stmeld-nr-26-199 9-2000-/id192850/?qstortingsmelding\%2026\%20 (nedlastet 25.09.2018) 
4. St. Meld. 11 (2015-2016). Nasjonal helse- og sykehusplan. Oslo: Helse- og

omsorgsdepartementet; 2015. Tilgjengelig fra: https://

www.regjeringen.no/no/tema/helse-og-omsorg/sykehu

s/nasjonal-helse-og-sykehusplan2/id2461509/

(nedlastet 25.09.2018)

5. Lov 2. juli 1999 nr. 61 om pasient- og brukerrettigheter (pasient- og brukerrettighetsloven).

Tilgjengelig fra: https://lovdata.no/dokument/NL/lov/1 999-07-02-63 (nedlastet 25.09.2018)

6. Aarthun A, Akerjordet K. Parent participation in decision-making in health-care services for children: an integrative review. J Nurs Manag. 2014;22:177-91. 